\title{
The Acceptance of M-Heutagogical Practice in Higher Education: A Systematic Literature Review
}

\author{
https://doi.org/10.3991/ijet.v16i22.25625 \\ Analisa Hamdan, Kung-Teck Wong ${ }^{(凶)}$, Nor Syazwani Mat Salleh, \\ Hafizul Fahri Hanafi \\ Sultan Idris Education University, Perak, Malaysia \\ thomas afpm.upsi.edu.my
}

\begin{abstract}
Mobile Heutagogy (M-Heutagogy) is the teaching practice that emphasizes self-determined learning and student autonomy. Many teachers and academicians have applied M-Heutagogy in their teaching and learning in Higher Education Institutions (HEIs). The purpose of this study is to synthesize an empirical literature review of the M-Heutagogical practice among Higher Education students and its acceptance. The main objective of this paper is to review the literature on M-Heutagogy practice and its acceptance among Higher Education students. The researcher conducted a systematic review of 60 articles for the period 2007 to 2020. The findings indicate that M-Heutagogy has been applied in HEIs around the world with the support of emergent technologies and mobile applications. Unfortunately, only two M-Heutagogy acceptance studies have been done so far. Future research suggested that the M-Heutagogy acceptance model should be developed to be referred by researchers while doing an acceptance study.
\end{abstract}

Keywords—heutagogy, mobile heutagogy, self-determined learning, acceptance

\section{Introduction}

The rapid technological innovation over the past decade has dramatically raised the diversity of ways that teaching and learning can take place. Learning has no longer take place only in a classroom; they have gone mobile via the use of mobile technologies and applications. Besides, learning has also been blended with a combination of traditional learning, online learning, and self-directed learning. As a consequence, learning has created interest among students and developed active learning that occurs anywhere at any time [1] [61]. The speed of Web 2.0 and Web 3.0 technology has also led to a change in the state of the facilities provided by Higher Education Institutions (HEIs) to support 21 st-century education. As such, the Ministry of Higher Education (MOHE) has introduced Education 4.0 that in line with the Industrial Revolution 4.0 (IR4.0) through the Amanat 2018 (MOHE, 2018). Education 4.0 is an educational transformation where information is available everywhere, and the teaching and learning process is dynamic [2] [32]. In line with the needs and challenges of the 21 st century, the 
concept of higher education should have redefined, taking into account learning content, learning approaches, and teaching technologies [3]. Therefore, HEIs were encouraged to reform their higher education system and take the initiative to implement teaching and learning.

Due to IR4.0, HEIs need to ensure that the produced human capital has the knowledge and skills such as mastery learning, collaborative learning, and 21st Century Learning. However, teacher-centered andragogy and pedagogical methods are no longer sufficient to prepare students for 21 st-century career challenges [4]. Therefore, a suitable student-centered technological-based pedagogical approach is needed to overcome the circumstances. In other words, the student-centered technological-based pedagogical approach is essential to increase student engagement and autonomy and excitement in learning. In line with the MOHE's commitment to improving the country's education system, the Ministry has proposed a new approach to teaching and learning, the 21st Pedagogy [5]. Heutagogy, paragogy, and cybergogy have been promoted for inclusion in the new T\&L approach. Heutagogy refers to self-determination learning, whereas paragogy is peer-oriented learning. Meanwhile, cybergogy refers to virtual-based learning comprising MOOC implementation and blended learning [6]. However, based on previous studies, heutagogy has been highlighted more than paragogy and cybergogy [7].

Heutagogy approach is a powerful tool that prioritizes active students' engagement. Heutagogy emphasizes the elements of ability, student autonomy, and active learning processes such as reflection and interaction [8]. This heutagogical approach enhanced by the use of mobile technology and the latest Web 2.0 applications, known as Mobile Heutagogy (M-Heutagogy) [9]. The availability of online technologies seems to support the growth of M-Heutagogy. M-Heutagogy applies the latest digital technology to teaching and learning (T\&L) activities such as Kahoot! Quizizz, Flipgrid, and Facebook [10]. M-Heutagogy encourages active student engagement and enhances student autonomy. Recently, M-Heutagogy is gaining acceptance and has begun its implementation in education in schools and higher learning institutions around the world [11-24]

This paper aims to present an overview of the existing research on the M-Heutagogy. For this purpose, a systematic literature review will be performed. The aim of reviewing systematically is to have such explicit, rigorous, and accountable methods [25]. Besides, systematic reviews aim to reduce bias through published and unpublished studies' extensive literature searches, besides providing an audit path of the reviewer's decision-making [25]. Therefore, the main objective of this paper is to review the literature on M-Heutagogy practice and acceptance among undergraduate students.

\section{Methodology}

This study seeks to synthesize the existing literature on M-Heutagogical practice in HEIs. This work was driven by investigating two research questions as: "What empirical research has been done on the M-Heutagogical practice in Higher Education?" and "What empirical research has been done on the acceptance of M-Heutagogical practice among Higher Education students?" Seven databases used to search relevant literature, 
which is EBSCOhost, Emerald Insight, ProQuest, Sage Publication, Science Direct, Springer Link, and Google search engine.

The following keywords were used in this study: heutagogy, mobile-heutagogy, selfdetermined learning, and heutagogy acceptance. Besides, articles published before 2007 were excluded and to include only recent research. Boolean search terms "AND" and "OR" are used to limit our searches. Only peer-reviewed studies and published in a scholarly journal (magazines and newspapers were excluded) between 2010 and 2020 are included in this review. Eligible studies also needed to be published in English or Malay language with students from Higher Education settings. The results of the information search are summarized in Table 1.

Table 1. The Total Articles Classified by the Databases

\begin{tabular}{|l|c|c|c|c|}
\hline \multirow{2}{*}{ Databases } & \multicolumn{4}{|c|}{ Keywords } \\
\cline { 2 - 5 } & Heutagogy & Mobile-Heutagogy & Self-determined learning & Heutagogy Acceptance \\
\hline EBSCOhost & 16 & 2 & 15 & 0 \\
\hline Emerald Insight & 4 & 0 & 3 & 0 \\
\hline Google & 8 & 2 & 4 & 2 \\
\hline ProQuest & 25 & 0 & 44 & 6 \\
\hline Sage Publication & 2 & 0 & 2 & 3 \\
\hline Science Direct & 9 & 0 & 9 & 2 \\
\hline Springer Link & 20 & 0 & 23 & 14 \\
\hline Total & 84 & 4 & 100 & 14 \\
\hline
\end{tabular}

\subsection{Selection of primary studies}

Based on Table 1, a total of 202 articles has been retrieved from the databases. However, a few articles are duplicates due to the keywords "heutagogy" and "self-determined learning." Therefore, an exclusion process has been done based on the repeated articles from the two keywords. As a result, 56 review articles with the keywords "heutagogy" and "self-determined learning" has been selected in this study. Next, four articles from the keyword "Mobile Heutagogy" were duplicate to each other. With the same exclusion procedure as above, only two articles are selected. For the "heutagogy acceptance" keyword, 14 review articles have been retrieved from the databases. The acceptance criteria for this study need to include the type of acceptance model and theories such as the Unified Theory of Acceptance and Use of Technology (UTAUT) and Technology Acceptance Model (TAM). Based on the exclusion process, only two articles have been identified to include UTAUT in the acceptance studies. Therefore, the two articles will be included in this study. Hence, 60 peer-reviewed journal articles have been selected to be reviewed in this study. 


\section{Results and discussion}

The finding of the two research questions has been discussed in this section. The systematic review findings can be summarized as below.

\subsection{Research question 1: What empirical research has been done on the M- Heutagogical practice in higher education?}

Firstly, past studies findings show that heutagogy has been applied as a supplementary approach to primary pedagogy in the teaching and learning activities at the Higher Education environment [11-31]. For instance, the heutagogy approach was implemented in mobile learning for lifelong learning [11] [29] [30] [48]. This means that heutagogy has been treated as an approach by the teachers to accomplish the teaching process. Even though the approach is just to add-on to pedagogy, it will give benefits to students as students will be autonomous learners. The autonomous learner will be able to determine their learning objectives, planning their learning content and activities [33]. Besides, they can choose their preferred tools and assessment [34] [35] [36]. When they can decide on their learning, the learning process will be smooth, engaging, and the learning objectives will be accomplished.

The second point is the term heutagogy has just started to be used extensively. Before 2010, a few studies used the term self-determination learning. Heutagogy has begun to be implemented in teaching and learning as early as 2000 [37]. However, the approach has become popular in 2018, as there is an urge from the Ministry of Higher Education to increase the quality of learning [37] [38]. Besides, many research findings have identified the benefits of heutagogy practice, such as skills, engagement, self-reflect, and self-motivation among the students, are essential skills needed to survive in the 4IR challenges [39-42]. The changes role of educators is also one of the strengths of heutagogy [29] [38]. Therefore, heutagogy should be carried out thoroughly so that the first focus of the government's goals is achieved.

The third point is most studies applied the heutagogy approach together with the use of emerging technologies or mobile applications [43] [44]. Even though the term used is heutagogy, but it is understandable that the teachers and students used technologies in their teaching and learning activities and assessments. Besides, the term self-determination learning used by a few studies has also integrated technologies in the teaching and learning process. A few studies have been identified to use mobile heutagogy to refer to the learning approach used [3] [44] [47]. Thus, no matter which terms has been used, mobile technologies and applications will be integrated as support tools in 21stcentury learning.

The fourth point will focus on the methodology used in past studies. Based on the reviews, quantitative and qualitative method has been applied in the research [44-59] [66]. The survey, focus group, observation, and interviews are the techniques used in past studies to get an overview related to heutagogy or self-determined learning. Only a few studies are concept papers that discussed in detail about the heutagogical practice in Higher Education settings [49] [58]. Thus, to extend the heutagogy research, future researches are advised to apply any techniques that can lead to detailed information 
about M-Heutagogy. For example, the Fuzzy Delphi Method (FDM) technique can be applied in the Design and Development Research (DDR). FDM is a technique used to get a consensus from the experts about the questionnaire items. The advantages of FDM are it will save cost and time, reduce the number of surveys and interviews, and quick opinions received by the experts [62] [63]. Based on the review, only a study applied FDM to get the expert validation for the instrument [45]. Hence, it is advisable to try new techniques in a heutagogy related study.

The final point is all countries in the world, including Malaysia, have started to implement the M-Heutagogical practice in Higher Education. This includes all fields such as education, business, music education, and nursing. In other words, M-Heutagogy can be implemented in any area as long as it is implemented in universities, technical and vocational institutions, colleges, and high schools. Distance learning education institutions can try to apply the M-Heutagogy to the students and used suitable technologies such as Zoom, Microsoft Teams, Nearpod, and Learning Management System (LMS) [43] [64]. To use M-Heutagogy, educators need to give autonomy to students to decide their learning objectives, contents, activities, and assessments [12] [38-41]. If there is no autonomy given to students, the learning is not using the M-Heutagogy approach, but the learning can only be considered as blended learning [61]. Thus, a proper guideline on how to implement an M-Heutagogy approach is needed, especially to the new teachers, trainee-teachers, and distance learning institutions.

\subsection{Research question 2: What empirical research has been done on the acceptance of M-Heutagogical practice among higher education students?}

Based on the reviews, only two articles employed acceptance theory and model, which is UTAUT in the M-Heutagogy acceptance study [3] [11]. Another 58 reviewed articles did not study the acceptance of heutagogy or self-determined learning; instead, most of the studies are still developing suitable heutagogical framework. M-Heutagogy is considered a new study even though there is evidence that shows heutagogy was applied many years ago. The findings of past studies show that Malaysia has just started to apply M-Heutagogy lately. In contrast, other countries such as Germany, New Zealand, Australia, the United Kingdom, and the United States of America have used it earlier. Even though the countries have started to include a heutagogy approach in their teaching and learning process, therefore there is no evidence that they are doing the acceptance study. Acceptance study is essential when a new method, planning, or innovation has been developed and implemented [65] [68]. Therefore, an acceptance study related to M-Heutagogy should be done to get more information about the predictors towards the intention to use M-Heutagogy in higher education. The information received can be used by all stakeholders, including the teachers, to upgrade teaching planning or enhance teaching activities. Indirectly, the quality of higher education will be increased.

Based on the articles reviewed related to the acceptance of M-Heutagogy, the level of heutagogy acceptance is considered high as most items were at high levels [11]. Social influence from the lecturers towards the students' intention to use the heutagogy 
approach in m-learning is essential to increase students' motivation. Besides, the students' acceptance relationship towards the elements of heutagogy is very strong. This means that if the students' level of acceptance is high, the heutagogy elements level will also high. Thus, an acceptance study is needed to find out the level of students' acceptance to use M-Heutagogy in their learning.

Besides, the study finding from [3] [67] shows that there were factors that contribute towards M-Heutagogy practices. Use Expectancy (UE), Facilitating Condition (FC), Social Influence (SI), and Mobile Teacher Efficacy (MTE) were significant factors of behavioral intention (BI). In other words, all four predictors in their conceptual framework, especially MTE, are significant towards the behavioral intention to implement the M-Heutagogy practice. The MTE is highly significant due to $\mathrm{Y}$ and $\mathrm{Z}$ teachers' generations who spend more time with technologies, especially related to mobile learning [69]. Therefore, the MTE variables should be explored in-depth to get rich information about the M-Heutagogy practice. Furthermore, exogenous variables such as learner autonomy, learning styles, performance expectancy, and effort expectancy can be studied towards behavioral intention. It is because the variables have been identified to be the best predictors in m-learning and blended learning studies [24] [46] [60]. Hence, researchers should consider these variables in future acceptance studies.

\section{Conclusion}

Majority past studies have applied the M-Heutagogical approach in HEIs, whether as the primary teaching approach or supplementary to the primary pedagogy. The effect of implementing M-Heutagogy into teaching and learning will gain students' interest in learning. Students will feel appreciable as the teachers gave them opportunities to decide their learning objectives, learning contents, activities as well as assessments. They can also choose their learning tools such as Zoom to video conferencing with teachers and friends, SlideShare to share their slides, and Twitter to discuss among themselves. The emergent technologies will give many advantages to students and teachers to facilitate learning. Acceptance study related to the implementation of MHeutagogy is crucial to be done to improve teaching and learning planning and process. Future work will include the development of the M-Heutagogy Acceptance Model, which will be referred to by researchers while doing an acceptance study. The variables that have the potential to be predictors to behavioral intention to use M-Heutagogy among Higher Education students should be studied further.

\section{$5 \quad$ Acknowledgment}

Great appreciation is communicated to Sultan Idris Education University (UPSI), Perak, Malaysia for the research grant (2019-0122-107-01) and the Ministry of Education (MOE) Malaysia for the support of this research. 


\section{References}

[1] Little, B. (2012). "Effective and efficient mobile learning: issues and tips for developers," Industrial and Commercial Training, vol. 44, no. 7, pp. 402-407, 2012. https://doi.org/ $\underline{10.1108 / 00197851211267983}$

[2] Halili, S. H. (2019). "Technological Advancements in Education 4.0," The Online Journal of Distance Education and e-Learning, vol. 7, no. 1, pp. 63-69.

[3] Wong, K-T., Yeop, M.A. and Muhammad, M@M. (2019). “Modelling the Factor Influencing the Implementation of Mobile-Heutagogical Practices among Teachers: An Application of Invariance Multi-Group Structural Model," International Journal of Learning, Teaching and Educational Research, vol. 18, no. 12, pp. 1-16. https://doi.org/10.26803/ijlter.18.12.1

[4] Eachempati, P., Kumar, K.KS., Komattil, R. and Ismail, A.R.H. (2017). "Heutagogy through Facebook for the Millennial learners", MedEdPublish, vol. 6, no. 4, pp. 1-12. https://doi.org/10.15694/mep.2017.000194

[5] Ministry of Higher Education. (2018). Framing Malaysia Higher Education 4.0: Futureproof talents, Putrajaya, Malaysia: Department of Higher Education Malaysia Ministry of Higher Education Malaysia. https://doi.org/10.30880/jtet.2021.13.02.001

[6] Sani, R. (2018). "Embracing industry 4.0," New Straits Times, January 17, 2018. https://www.nst.com.my/education/2018/01/325914/embracing-industry-40

[7] Malek, J. A. (2017). "The impact of heutagogy education through telecentre in smart village (SV)," e-Bangi, vol. 14, no. 2 .

[8] Hase, S. and Kenyon, C. (2000). "From andragogy to heutagogy," Ulti-BASE In-Site.

[9] Narayan, V. and Herrington, J. (2014). "Towards a theoretical mobile heutagogy framework," presented at ASCILITE 2014: The Rhetoric and Reality: Critical perspectives on educational technology, Dunedin.

[10] Atherton, P. (2018). 50 Ways to Use Technology Enhanced Learning in the Classroom: Practical Strategies for Teaching. Learning Matters.

[11] Kamrozzaman, N. A., Badusah, J. and Mohammad, W.M.R.W. (2019). "Heutagogy Approach: Effectiveness of M-Learning for Lifelong Learning Education/Pendekatan heutagogi: Keberkesanan M-pembelajaran untuk pendidikan sepanjang hayat," Sains $\mathrm{Hu}$ manika, vol. 11, no. 3, pp. 53-61. https://doi.org/10.11113/sh.v11n3.1496

[12] Blaschke, L. M. (2016). "Strategies for implementing self-determined learning (heutagogy) within education: A comparison of three institutions (Australia, South Africa, and Israel)". M.A. thesis, Carl von Ossietzky Universität Oldenburg, Oldenburg.

[13] Chan, C.G., Embi, M. A. and H. Hashim, H. (2019). "Primary school teachers' readiness towards heutagogy and peeragogy," Asian Education Studies, vol. 4, no. 1, pp. 11-21. https://doi.org/10.20849/aes.v4i1.602

[14] Chan, C.S.C., Leng, P.G., Saidon, Z.L. and Lim, C.K. (2018). "Empowering Youth Performance of the Living Multicultural Heritage of Tanjong Malim through a Heutagogical Approach," in Proceedings of the 3rd International Music and Performing Arts Conference, 2018, pp. 37-45.

[15] Jones, C. Penaluna, K. and Penaluna, A. (2019). "The promise of andragogy, heutagogy and academagogy to enterprise and entrepreneurship education pedagogy," Education + Training, vol. 61, no. 9, pp.1170-1186. https://doi.org/10.1108/ET-10-2018-0211

[16] Agonács, N., and Matos, J.F. (2019). "Heutagogy and self-determined learning: A review of the published literature on the application and implementation of the theory," Open Learning: The Journal of Open, Distance and e-Learning, vol. 34, no. 3, pp. 223-240. https://doi.org/10.1080/02680513.2018.1562329 
[17] Levy-Feldman, I. (2018). "The good teacher for the twenty-first century: a "mentoring teacher" with heutagogical skills," International Journal of Mentoring and Coaching in Education, vol. 7, no. 2, pp. 177-190. https://doi.org/10.1108/IJMCE-10-2017-0067

[18] Yusoff, A.N.M., Mohammad, R., Ali, N. and Aziz, S.A. (2018). "ID NO. UPM002 TOPIC: Memperkasakan Gamifikasi Dalam Hieps 4.0 MPU Via 'Tools' Heutagogi," University Carnival on e-Learning (IUCEL), pp. 389-391.

[19] Ayub, E. (2018). "TOPIC: A SMART Future Classroom in VLE for a Massive Number of Students: A Solution for Instructor and Classroom Shortages," University Carnival on eLearning (IUCEL).

[20] Kedin, N.A., Sulaiman, S.B., Saari, I.Z., Hamid, A.S.A. and Zahidi, N.E. (2018). "ID NO. UiTM006 TOPIC: "Heutagogy Approach: Exploring Statistics in MOOC," University Carnival on e-Learning (IUCEL), pp.148-150.

[21] Wahiza, W. and F. Idris, F. (2017). "Pendekatan Heutagogi dalam Pendidikan Citra UKM abad ke-21, "In The 2017 International Conference on Education and Development (ICERD 2017).

[22] Bailey, M. M. (2013). "Developmentalism - from here to there - is heutagogy the way there for HR?" Doctor of Education thesis, University of Stirling.

[23] Bhoyrub, J., Hurley, J., Neilson, G.R., Ramsay, M. and Smith, M. (2010). "Heutagogy: An alternative practice-based learning approach," Nurse education in practice, vol. 10, no. 6, pp. 322-326. https://doi.org/10.1016/j.nepr.2010.05.001

[24] Ashton, J. and Elliott, R. (2007). "Juggling the balls - Study, work, family and play: Student perspectives on flexible and blended heutagogy," European Early Childhood Education Research Journal, vol. 15, no. 2, pp. 167-181. https://doi.org/10.1080/13502930701321378

[25] Gough, D., Thomas, J. and Oliver, S. (2012). "Clarifying differences between review designs and methods," Systematic reviews, vol. 1, no.1, pp. 1-9. https://doi.org/10.1186/20464053-1-28

[26] Mulrennan, D. (2018). "Mobile social media and the news: where heutagogy enables journalism education," Journalism \& Mass Communication Educator, vol. 73, no. 3, pp. 322333. https://doi.org/10.1177/1077695817720762

[27] Gregory, S., Bannister-Tyrrell, M., Charteris, J. and Nye, A. (2018). "Heutagogy in Postgraduate Education: Cognitive Advantages for Higher Degree Online Students," In Postgraduate Education in Higher Education, F. Padró, R. Erwee, M. Harmes, M. Harmes, P. Danaher, Eds. Singapore: Springer, pp.189-191. https://doi.org/10.1007/978-981-10-5249132

[28] AlFuqaha, I. N. (2013). "Pedagogy redefined: frameworks of Learning Approaches Prevalent in the Current Digital Information Age," Journal of Educational Technology, vol. 10, no. 1, pp. 36-45. https://doi.org/10.26634/jet.10.1.2302

[29] Blaschke, L.M. (2012). "Heutagogy and lifelong learning: a review of heutagogical practice and self-determined learning," The International Review of Research in Open and Distributed Learning, vol. 13, no. 1. https://doi.org/10.19173/irrodl.v13i1.1076

[30] Carr, A., Balasubramanian, K., Atieno, R. and Onyango, J. (2018). "Lifelong learning to empowerment: beyond formal education," Distance Education, vol. 39, no. 1, pp. 69-86. https://doi.org/10.4324/9780429292941-6

[31] Canning, N. (2010). "Playing with heutagogy: Exploring strategies to empower mature learners in higher education," Journal of Further and Higher Education, vol. 34, no. 1, pp. 59-71. https://doi.org/10.1080/03098770903477102

[32] Jamaludin, R., McKAY, E. and Ledger, S. (2020). "Are we ready for Education 4.0 within ASEAN higher education institutions? Thriving for knowledge, industry and humanity in a 
dynamic higher education ecosystem?" Journal of Applied Research in Higher Education, vol.12, no. 5, pp. 1161-1173. https://doi.org/10.1108/jarhe-06-2019-0144

[33] Lin, L. and Reinders, H. (2017). "Assessing learner autonomy: development and validation of a localized scale." in Innovation in Language Learning and Teaching, Reinders, H., Nunan, D. and Zou, B. Eds. London: Palgrave Macmillan, pp. 307-328. https://doi.org/ 10.1057/978-1-137-60092-9_14

[34] Vurdien, R. and Puranen, P. (2020). "Enhancing students' intercultural competence and learner autonomy via facebook telecollaboration," in Multicultural Instructional Design: Concepts, Methodologies, Tools, and Applications, Hershey, PA: IGI Global, pp. 646-666. https://doi.org/10.4018/978-1-5225-9279-2.ch030

[35] Hasim, Z. and Zakaria, A. R. (2015). "ESL Teachers' knowledge on learner autonomy," In Knowledge, Service, Tourism \& Hospitality: Proceedings of the Annual International Conference on Management and Technology in Knowledge, Service, Tourism \& Hospitality 2015 (SERVE 2015), F.L. Gaol, F. Hutagalung, A.R. Zakaria and Z. Hasim, Eds. CRC Press, pp. 3-6. https://doi.org/10.1201/b21184-3

[36] Chan, V., Spratt, M. and Humphreys, G. (2002). "Autonomous language learning: Hong Kong tertiary students' attitudes and behaviours'," Evaluation \& Research in Education, vol. 16 no. 1, pp. 1-18. https://doi.org/10.1080/09500790208667003

[37] Ministry of Higher Education, (2018). Amanat Menteri Pendidikan Tinggi 2018, Putrajaya: Kementerian Pendidikan Malaysia.

[38] Blaschke, L. M. and Hase, S. (2015). "Heutagogy, technology, and lifelong learning for professional and part-time learners," in Transformative perspectives and processes in higher education, A. Dailey-Hebert and K. Dennis, Eds. Cham: Springer, pp. 75-94. https://doi.org/10.1007/978-3-319-09247-8 5

[39] Blaschke, L. M. (2018). "Self-determined learning (heutagogy) and digital media creating integrated educational environments for developing lifelong learning skills," in The Digital Turn in Higher Education, D. Kergel, B. Heidkamp, P. Telléus, T. Rachwal and S. Nowakowski, Eds. Wiesbaden: Springer VS, pp. 129-140. https://doi.org/10.1007/978-3$\underline{658-19925-8 \quad 10}$

[40] Blaschke, L. M. and Hase, S. (2016). "Heutagogy: A holistic framework for creating twentyfirst-century self-determined learners," in the future of ubiquitous learning, B. Gros, Kinshuk, M. Maina, Eds. Berlin, Heidelberg: Springer, pp. 25-40. https://doi.org/10. 1007/978-3-662-47724-3 2

[41] Blaschke, L. M., Kenyon, C. and Hase, S. (2014). "Experiences in self-determined learning," Oldenburg, Germany: CreateSpace Independent Publishing Platform.

[42] Coelho, F. J. M., Marques, C., Loureiro, A. and Ratten, V. (2018). "Evaluation of the impact of an entrepreneurship training program in Recife, Brazil," Journal of Entrepreneurship in Emerging Economies, vol. 10, no. 3, pp. 472-488. https://doi.org/10.1108/JEEE-10-2017$\underline{0077}$

[43] Cochrane, T., Antonczak, L., Gordon, A., Sissons, H. and Withell, A. (2012). "Heutagogy and mobile social media: Post web 2.0 pedagogy," In Proceedings Ascilite Wellington 2012, 2012, pp. 204-214.

[44] Narayan, V., Herrington, J. and Cochrane, T. (2019). "Design principles for heutagogical learning: Implementing student-determined learning with mobile and social media tools," Australasian Journal of Educational Technology, vol. 35, no. 3, pp. 86-101. https://doi.org /10.14742/ajet.3941

[45] Kamrozzaman, N. A., Badusah, J. and Mohammad, W.M.R.W. (2020). "Development of heutagogy approach in M-learning for sustainability education," Education and Information Technologies, vol. 25, pp. 3035-3047. https://doi.org/10.1007\%2Fs10639-020-10101-x 
[46] Wong, K-T., Hwang, G. J., Goh, P. S. C., and Arrif, S. K. M. (2018). "Effects of blended learning pedagogical practices on students' motivation and autonomy for the teaching of short stories in upper secondary English," Interactive Learning Environments, vol. 28, no. 4, pp. 512-525. https://doi.org/10.1080/10494820.2018.1542318

[47] Wong, K-T., Muhammad, M.@M. b., Abdullah, N. b. and Hamdan, A. (2020). "Mobileheutagogical practices among student teachers: its pedagogical affordances and challenges," International Journal of Interactive Mobile Technologies (iJIM), vol. 14, no. 2, pp. 130-143. https://doi.org/10.3991/ijim.v14i02.11819

[48] Talati, J. J. (2014). "Lifelong learning: Established concepts and evolving values," Arab Journal of Urology, vol. 12, no. 1, pp. 86-95. https://doi.org/10.1016/j.aju.2013.11.001

[49] Smith, M. (2017). "Using andragogy to teach pedagogy: expecting heutagogy-using againstthe-grain teaching practices for desired outcomes," Research in Teacher Education, vol. 7, no. 1 , pp. 13-18.

[50] Dunn, T. J. and Kennedy, M. (2019). "Technology Enhanced Learning in higher education; motivations, engagement and academic achievement," Computers \& Education, vol. 137, pp. 104-113. https://doi.org/10.1016/j.compedu.2019.04.004

[51] Von der Heidt, T. and Quazi, A. (2013). "Enhancing learning-centeredness in marketing principles curriculum," Australasian Marketing Journal (AMJ), vol. 21, no. 4, pp. 250-258. https://doi.org/10.1016/j.ausmj.2013.08.005

[52] Bali, M. and Caines, A. (2018). "A call for promoting ownership, equity, and agency in faculty development via connected learning," International Journal of Educational Technology in Higher Education, vol. 15, no. 46, pp. 1-24. https://doi.org/10.1186/s41239-018$\underline{0128-8}$

[53] Northcote, M. and Boddey, C. (2014). "Using the self-determined learning principles of heutagogy to support academic staff who are learning to teach online," presented at the Australasian Society for Computers in Learning in Tertiary Education Conference, Dunedin, New Zealand, pp. 735-739.

[54] Eberle, J. and Childress, M. (2005). "Using heutagogy to address the needs of online learners," In Encyclopedia of distance learning, Hershey, PA: IGI Global, pp. 1945-1951. https://doi.org/10.4018/978-1-59140-555-9.ch297

[55] Nkuyubwatsi, B. (2016). "The outcome of constructive alignment between open educational services and learners' needs, employability and capabilities development: Heutagogy and transformative migration among underprivileged learners in Rwanda," Cogent Education, vol. 3, no. 1. https://doi.org/10.1080/2331186x.2016.1198522

[56] Thakur, G. R. (2017). "Heutagogical Learning Efficiency Model to ICT Integration in the Classroom," International Scientific Journal of Contemporary Research in Engineering, Science and Management (ISJCRESM), vol. 2, pp. 1-5.

[57] Salmi, H. and Thuneberg, H. (2019). "The role of self-determination in informal and formal science learning contexts," Learning Environments Research, vol. 22, no. 1, pp. 43-63. https://doi.org/10.1007/s10984-018-9266-0

[58] Snowden, M. and Halsall, J. P. (2016). "Self-determined approach to learning: A social science perspective," Cogent Education, vol. 3, no. 1. https://doi.org/10.1080/2331186X. $\underline{2016.1247608}$

[59] Green, J. K. and Huntington, A. D. (2017). "Online professional development for digitally differentiated nurses: An action research perspective," Nurse education in practice, vol. 22, pp. 55-59. https://doi.org/10.1016/j.nepr.2016.11.009 
[60] Giesbers, B., Rienties, B., Tempelaar, D.T., and Gijselaers, W. (2014). "Why increased social presence through web videoconferencing does not automatically lead to improved learning," E-Learning and Digital Media, vol. 11, no. 1, pp. 31-45. https://doi.org/10.2304/ elea.2014.11.1.31

[61] Noh, N., Abdullah, N., Wong, K-T. and Hamzah, M. (2019). “Cultivating Blended Learning in Teaching and Learning: Teachers' Intrinsic and Extrinsic Readiness in Malaysia," International Journal of Academic Research in Business and Social Sciences, vol. 8, no. 2. https://doi.org/10.6007/ijarped/v8-i2/5778

[62] Tee, Y. Q., Mohamed, A., and Alias, N. (2014). "Application of fuzzy Delphi method in exploring Facebook as a tool for writing therapy among young adults," Malaysian Online Journal of Educational Technology, vol. 2, no. 3, pp. 1-10.

[63] Mohd, R., Siraj, S. and Hussin, Z. (2018). "Aplikasi kaedah Fuzzy Delphi dalam pembangunan modul pengajaran pantun Melayu berasaskan maksud al-Quran mengenai keindahan flora, fauna dan langit tingkatan 2 (Fuzzy Delphi Method Application in Developing Model of Malay Poem based on the Meaning of the Quran about Flora, Fauna and Sky Form 2), ” Jurnal Pendidikan Bahasa Melayu, vol. 8, no. 2, pp. 57-67. https://doi.org/ 10.37134/peradaban.vol12.1.2017

[64] Bozkurt, A. (2019). "The historical development and adaptation of open universities in Turkish context: case of Anadolu University as a giga university," International Review of Research in Open and Distributed Learning, vol. 20, no. 4, pp. 36-59. https://doi.org/ 10.19173/irrodl.v20i4.4086

[65] Stigka, E. K., Paravantis, J. A., and Mihalakakou, G. K. (2014). "Social acceptance of renewable energy sources: a review of contingent valuation applications," Renewable and Sustainable Energy Reviews. vol. 32, pp. 100-106. https://doi.org/10.1016/j.rser.2013.12.026

[66] Neck, H. M. and Corbett, A. C. (2018). "The scholarship of teaching and learning entrepreneurship," Entrepreneurship Education and Pedagogy, vol. 1, no. 1, pp. 8-41. https://doi.org/10.1177/2515127417737286

[67] Wong, K. T. Muhammad, M. and Abdullah, N. (2020). "Exploring the drivers of intention to use interactive whiteboards among Malaysia university students: Does technology selfefficacy matter?" International Journal of Emerging Technologies in Learning (iJET), vol. 15, no. 1, pp. 163-175. https://doi.org/10.3991/ijet.v15i01.11497

[68] Wong, K. T., Abdullah, N. and Goh, P. S. C. (2019). "A Cross Examination of the Intention to Integrate MOOCs in Teaching and Learning: An Application of Multi-Group Invariance Analysis," International Journal of Emerging Technologies in Learning (iJET), vol. 14, no. 19, pp. 106-116. https://doi.org/10.3991/ijet.v14i19.10642

[69] Yuan, Z. and Lu, Z. (2019). "College English Teaching Status and Individualized Teaching Design in The Context of Mobile Learning," International Journal of Emerging Technologies in Learning (iJET), vol. 14, no. 12, pp. 85-96. https://doi.org/10.3991/ijet.v14i12.10704

\section{$7 \quad$ Authors}

Analisa Hamdan is a doctoral student in Faculty of Human Development, Sultan Idris Education University, 35900 Tanjong Malim, Perak (Email: analisa.hamdan (a)gmail.com).

Kung-Teck Wong is an Associate Professor in Department of Educational Studies, Faculty of Human Development, Sultan Idris Education University, 35900 Tanjong Malim, Perak. 
Nor Syazwani Mat Salleh is a senior lecturer in Department of Art and Design, Faculty of Art, Computing and Creative Industry, Sultan Idris Education University, 35900 Tanjong Malim, Perak (Email: syazwani.ms@fskik.upsi.edu.my)

Hafizul Fahri Hanafi is a senior lecturer in Department of Art and Design, Faculty of Art, Computing and Creative Industry, Sultan Idris Education University, 35900 Tanjong Malim, Perak (Email: hafizul@fskik.upsi.edu.my)

Article submitted 2021-07-21. Resubmitted 2021-08-18. Final acceptance 2021-08-19. Final version published as submitted by the authors. 